\title{
SERVICES OF GENERAL ECONOMIC INTEREST - TOWARDS A EUROPEAN CONCEPT OF PUBLIC SERVICES
}

\author{
JAKUB KOCIUBIŃSKI*
}

\section{INTRODUCTION}

Services of General Economic Interest (SGEI) are in the middle of a clash between the antagonistic interests of competition versus welfare and social goals. Over the years the issue has gained prominence and moved to the very centre stage of a Europe-wide legal and political debate on the State's role in the market economy. Of course the Services in question are only one of the multitude of strands that shape the debate over the junction between European economic law and the social goals Member States may pursue.

The point of departure would be the establishment of roughly common terminology, or a conceptual framework to continue with analysis of the issue at hand. Indeed, a cohesive system of legal definitions is of key importance; as Ulla Neergaard pointed out, 'legal consequences may vary severely depending on which legal concept a given activity will be categorized as'. At the same time, the terminology found in various documents adopted by the European Commission is often vague. Of course the very concept of Services of General Economic Interest has its origins in Article 106(2) of the Treaty on the Functioning of the European Union (TFEU) and it lies in the field of EU Competition Law. ${ }^{2}$ However, other concepts such as 'public service compensation' or 'State aid' also play an essential role in the legal environment of the services discussed. Hence it is necessary to embrace a larger view than one just limited to competition law to analyse the evolution of the role that Services of General Economic Interest play in the European Union.

DOI: $10.2478 /$ wrlae-2013-0027

* PhD candidate; LLM; University of Wroclaw, Department of International and European Law; kociubinski.jakub@prawo.uni.wroc.pl

${ }^{1}$ Ulla Neergaard, 'Services of General Economic Interest: The Nature of the Beast' in Markus Krajewski, Ulla Neergaard and Johan Van de Gronden (eds), The Changing Legal Framework for Services of General Economic Interest in Europe. Between Competition and Solidarity (DJØF 2009) 17.

${ }^{2}$ The Treaty on the Functioning of the European Union [2010] OJ L83/47. Subsequent citation of TFEU from this source. The wording of the provision has not changed since its adoption and therefore the current article number will be used in this paper unless in citation. 


\section{THE NOTION OF GENERAL ECONOMIC INTEREST}

The term 'Services of General Economic Interest' is nowhere defined in the Treaty. In 2000 the Communication Commission defined the services in question as 'market services which Member States or the Community subject to specific public service obligation by virtue of general interest criterion'. ${ }^{3}$ As Alison Jones and Brenda Sufrin observed, these services 'belong to the market, but to which other non-market values are applied' ${ }^{4}$ In acquis communautaire, the term Services of General Interest first surfaces in 1996 in the Communication Commission's paper Services of general interest in Europe. ${ }^{5}$ The 2003 Green Paper on services of general interest provides following definition of Services of General Interest: 'Market and non-market services which the public authorities class as being of general interest and subject to specific public service obligations'. ${ }^{6}$ It is thus apparent that this is an umbrella term encompassing both economic/market services which are subject to competition rules (unless the derogations encapsulated in Article 106(2) TFEU apply) and non-economic services which are beyond the scope of EU Competition Law. ${ }^{7}$ However, it must be noted following José Louis Buendia Sierra that the European Court of Justice (ECJ) has sometimes used the terms Services of General Interest and Services of General Economic Interest interchangeably. ${ }^{8}$ Nevertheless, two general elements of the definition of SGEI could be distinguished; the general interest they served and their economic component. ${ }^{9}$

Broadly speaking the term 'General Interest' is often equated with the Public Interest and its equivalents in the Member States (algemeen belang, d'intérêt public, interes publiczny etc.). ${ }^{10}$ For example, in German doctrine the concept of General Interest is often associated with the term Daseinsvorsorge coined by Ernst Forsthoff, while in France it is often equated

\footnotetext{
${ }^{3}$ Communication on services of general economic interest [2001] OJ C17/4.

${ }^{4}$ Alison Jones and Brenda Sufrin, EC Competition Law. Text, Cases and Materials (OUP 2007) 621.

${ }^{5}$ Commission Communications on services of general interest in Europe [1996] OJ C281/3.

${ }^{6}$ Commission Green Paper of 21 May 2003 on services of general interest [COM(2003) 270 final - not published in the Official Journal].

7 Communication from the Commission to the European Parliament, the Council, the European Economic and Social Committee and the Committee of the Regions, of 20 November 2007, accompanying the Communication on 'A single market for 21 st century Europe' - Services of general interest, including social services of general interest: a new European commitment [COM (2007) 725 final - not published in the Official Journal].

${ }^{8}$ José Louis Buendia Sierra, 'Article 86 - Exclusive Rights and Other Anti-competitive State Measures' in Jonathan Faull and Ali Nikpay (eds), The EC Law of Competition (OUP 2007) 584. See also Case C-393/92 Gemeente Almelo and Others v NV Energiebedrijf Ijsselmij [1994] ECR I-1477.

${ }^{9}$ Leonor Moral Soriano, 'How proportionate should anti-competitive state intervention be?' [2003] 28 EL Rev 114

10 Elisenda Malaret Garcia, 'Public Service, Public Services, Public Functions and Guarantees of Rights of Citizens: Unchanging needs in a Changed Context' in Mark Freedland and Silvana Sciarra (eds), Public Services and Citizenship in European Law. Public and labour law Perspectives (OUP 1998) 57.
} 
with the concept of service public. ${ }^{11}$ It is clear, however, that that there are significant differences in the forms of organisation of public services between Member States; that said, on a certain level of generality some common features can be identified ${ }^{12}$. These are; that the provision of public services is subject to the control of public authorities, and that the regulator has specific tools for intervention. ${ }^{13}$ It must be noted that the Commission consistently avoids making reference to any of the national concepts of these services. ${ }^{14}$ The communautaire term Services of General Economic Interest emphasises the independence of EU Law, which cannot be interpreted with reference to existing national preconceptions. ${ }^{15}$

Based on the wording of the provision, Article 106(2) TFEU applies to certain 'undertakings'. The ECJ in its landmark ruling in the Höfner case, which gave birth to a common understanding of the term in question, defines an undertaking as 'every entity engaged in an economic activity, regardless of the legal status of the entity and the way in which it is financed'. ${ }^{16}$ As such, entities do not have to be incorporated under company law or take any other legally recognised form to be deemed an undertaking. ${ }^{17}$ This formula, which is repeated in the jurisprudence as well as the Commission's decisions, indicates that both the scope and criteria of the discussed concept must be oriented towards the raison d'être of competition law. ${ }^{18}$ Therefore, questions of ownership are of no importance.${ }^{19}$ Both private and public entities qualified as 'undertakings' are subject to competition regulations in the same manner. ${ }^{20}$ Consequently, the functional concept of an undertaking means that associations of undertakings, regardless of the legal status of their organizational structure, can also be regarded as 'undertakings' for the purposes of competition law. ${ }^{21}$ The decisive aspect is whether an association

${ }^{11}$ Günther Hirsch, Frank Montag and Franz Jürgen Säcker (eds), Competition Law: European Community. Practice and Procedure. Article-by-Article Commentary (Sweet \& Maxwell 2007) 1293.

${ }^{12}$ Malaret Garcia (n 10) 57.

13 ibid

${ }^{14}$ Commission Communication (n 3).

${ }^{15}$ Hirsch, Montag and Säcker (n 11) 1293.

${ }^{16}$ Case C-41/90 Klaus Höfner and Fritz Elser v Macrotron GmbH [1991] ECR I-1979, para 21. A similar material-institutional concept of undertaking was for the first time taken by the ECJ in its ruling in joined cases 17/61 and 20/61 Klöckner-Werke und Hösch v High Authority of the European Coal and Steel Community [1962] ECR 653.

${ }^{17}$ Lars Kjølbye, Ali Nikpay and Jonathan Faull, 'Article 81' in Faull \& Nikpay (n 8) 188189.

${ }^{18}$ Hirsch, Montag and Säcker (n 11) 410.

${ }^{19}$ Commission Green Paper (n 6) para 21.

${ }^{20}$ Joined cases T-228/99 and T-233/99 Westedeutsche Landesbank Girozentrale and Land Hordrhein-Westfalen v Commission of the European Communities [2003] ECR II-435, para 193. See also cases T-128/98 Aéroports de Paris $v$ Commission of the European Communities [2002] ECR I-9297, para 128 and T-114/02 BaByliss $v$ Commission of the European Communities [2003] ECR II-1191, para 114. Furthermore, the principle of neutrality encapsulated in article 345 TFEU precludes different treatment of undertakings based on their ownership structure. See also joined cases T-116/01 and T-118/01 $P$ \& O European Ferries (Vizcaya), SA \& Diputación Foral de Vizcaya $v$ Commission of the European Communities [2003] ECR II-2957, para 152.

${ }^{21}$ Peter Roth and Vivien Rose (eds), Bellamy \& Child: European Community Law of Competition. Sixth Edition (OUP 2008), para 2.031. See also cases T-102/92 Viho Europe BV Vizcaya $v$ Commission of the European Communities [1995] ECR II-117 para 50; T-9/99 
of the entities in question has as its purpose defining and furthering the economic interests of its members. ${ }^{22}$ Such an association does not have to be entrepreneurially active itself, as the activities of grouped entities are the decisive factor. ${ }^{23}$

For Article 106(2) TFEU to apply the entity in question must thus carry out economic activity. As per ECJ case law any activity consisting in offering goods and services on a given market is an economic activity. ${ }^{24}$ Pursuit of profit is not essential. ${ }^{25}$ Whether an entity could be considered an undertaking should be determined on a case-to-case basis, taking into account the circumstances specific to a given situation. ${ }^{26}$ Therefore, services provided as part of the prerogatives of the State, such as internal security or justice, are not economic activities and thus are outside the scope of Article 106(2) TFEU. ${ }^{27}$

Leonor Moral Soriano correctly pointed to the 'dual nature that Services of General Economic Interest have. On the one hand, they have an economic nature, for they are (...) market services; on the other, they have an implicit non-market nature, for they are provided in the general interest' ${ }^{28}$ Moreover, the Member States have wide competences in defining what services they consider to be provided in the general interest, only subject to control for manifest error of assessment. ${ }^{29}$ These are the main reasons behind

HFB Holding für Fernwärmetechnik Beteiligungsgesellschaft mbH \& Co. KG and Others v Commission of the European Communities [2002] ECR II-1487, paras 54 - 68

22 Case 48/69 Imperial Chemical Industries Ltd. (ICI) $v$ Commission of the European Communities [1972] ECR 619, paras 132, 134 - 135.

${ }^{23}$ Hirsch, Montag and Säcker (n 11) 431.

${ }^{24}$ Cases 118/85 Commission of the European Communities v Italy [1987] ECR 2599, para 7; C-35/96 Commission of the European Communities v Italy [1998] ECR I-3851, para 36; Joined Cases C-180/98 to 184/98 Pavel Pavlov and Others v Stichting Pensioenfonds Medische Specialisten [2000] ECR I-6451, para 75; C-475/99 Firma Ambulanz Glöckner v Landkreis Südwestpfalz [2001] ECR I-8089, para 19; C-309/99 J.C.J. Wouters, J.W. Savelbergh and Price Waterhouse Belastingadviseurs $B V v$ Algemene Raad van de Nederlandse Orde van Advocaten, intervener: Raad van de Balies van de Europese Gemeenschap [2002] ECR I-1577, para 47; C-82/01P Aéroports de Paris v Commission of the European Communities [2002] ECR II-3929, para 79.

${ }^{25}$ Film purchases by German television stations (Case IV/31.734) Commission Decision 89/536/EEC [1989] OJ L284/36 and Cases C-364/92 SAT Fluggesellschaft mbH v Eurocontrol [1994] ECR I-43; C-343/95 Diego Cali \& Figli Srl v Servizi ecologici porto di Genova SpA (SEPG) [1997] ECR I-1547; 52/76 Luigi Benedetti v Munari F.lli s.a.s. [1977] ECR 163

26 Joined Cases C-264/01, C-306/01, C-354/01 and C-355/01 AOK Bundesverband and Others v Ichtyol-Gesellschaft Cordes, Hermani \& Co. and Others [2004] ECR I-2493, para 63. See also Alexandr Svetlicinii, 'Back to the Basics: Concept of Undertaking and Economic Activity in SELEX Judgment' (2009) 12 European Law Reporter 422. It means that, though an entity may qualify as undertaking, it does not necessarily mean that competition rules apply to all of its activities (some may be deemed non-economic and therefore outside the scope of competition law).

${ }^{27}$ Based on case law, entities operating on the basis of 'solidarity' are not an undertaking. See Joined Cases C-159/91 and C-160/91 Christian Poucet v Assurances Générales de France and Caisse Mutuelle Régionale du Languedoc-Roussillon [1993] ECR I-637. See also Alexander Winterstein 'Nailing the Jellyfish: Social Security and Competition Law' (1999) 20 ECLR 324.

${ }^{28}$ Moral Soriano (n 9) 114.

${ }^{29}$ Commission Communication 2001 (n 3). See also Case T-289/03 British United Provident Association Ltd (BUPA), BUPA Insurance Ltd and BUPA Ireland Ltd v Commission of the European Communities [2005] ECR II-741, para 167. 
the lack of a clear and precise, authoritative and complete SGEI definition. ${ }^{30}$ The ECJ itself has never forged a general definition. It is, however, possible to create a sample list of activities that have been considered by the ECJ or by the Commission to be Services of General Economic Interest. These are: electricity distribution, ${ }^{31}$ the operation of certain inland waterways, ${ }^{32}$ water distribution, ${ }^{33}$ basic postal services, ${ }^{34}$ waste management. ${ }^{35}$ This list by no means aspires to be complete as both ECJ and the Commission have avoided as far as possible stating directly that a given activity is or is not a Service of General Economic Interest and prefers an ad casum approach. ${ }^{36}$

\section{SGEI AMONG SHARED VALUES OF THE EUROPEAN UNION}

Article 14 TFEU places Services of General Economic Interest among the 'shared values of the Union' and underlines 'their role in promoting social and territorial cohesion'. Furthermore, the Charter of Fundamental Rights includes in Article 36 a provision which recognises access to a given service in promoting 'the social and territorial cohesion of the Union'. ${ }^{37}$ Even before the adoption of these provisions an extensive but rather erratic case law had come into existence on Article 106(2) TFEU. ${ }^{38}$ The landmark Corbeau case that gave birth to the existing interpretation of Article 106 (2) TFEU was heard before Article 14 TFEU entered into force. ${ }^{39}$

\footnotetext{
${ }^{30}$ Mustafa T Karaygit 'The Notion of Services of General Economic Interest Revisited' (2009) 15 ERPL 575.

${ }^{31}$ Case C-393/92 Almelo (n 8).

${ }^{32}$ Case C-10/71 Ministère public luxembourgeois v Madeleine Muller, Veuve J.P. Hein and others (Haven von Mertert) [1971] ECR 723.

${ }^{33}$ NAVEVA-ANSEAU (Case IV/29.995) Commission Decision 82/371 [1982] L167/39.

${ }^{34}$ Cases C-320/91 Criminal proceedings against Paul Corbeau [1993] ECR I-2533 and C340/99 TNT Traco v Poste Italiane SpA and Others [2001] ECR I-4109. Also, on mainentance of postal service network in rural areas T-106/95 Fédération française des sociétés d'assurances (FFSA), Union des sociétés étrangères d'assurances (USEA), Groupe des assurances mutuelles agricoles (Groupama), Fédération nationale des syndicats d'agents généraux d'assurances (FNSAGA), Fédération française des courtiers d'assurances et de réassurances (FCA) and Bureau international des producteurs d'assurances et de réassurances (BIPAR) $v$ Commission of the European Communities [1997] ECR II-229.

${ }^{35}$ Cases C-209/98 Sydhavens Sten \& Grus ApS v Křbenhavns Kommune [2000] ECR I-3743 and C-203/96 Chemische Afvalstoffen Dusseldorp BV and Others v Minister van Volkshuisvesting, Ruimtelijke Ordening en Milieubeheer [1998] ECR I-4075.

${ }^{36}$ Erika Szyszczak, 'Public Services in Competitive Markets' (2001) 20 YEL 35. See also case 7/82, Gesellschaft zur Verwertung von Leistungschutzerechten mbH (GVL) v Commission of the European Communities [1983] ECR 483, paras 19 - 33 and Joined Cases C-34/01 to C-38/01 Enrisorse v Minnistero delle Finanze [2003] ECR I-14243, Opinion of AG Stix-Hackl, para 96.

${ }^{37}$ Charter of Fundamental Rights of the European Union OJ [2007] C303/1

${ }^{38}$ Leigh Hancher, 'Commuity, State and Market' in Paul Craig and Grainne de Búrca (eds), The Evolution of EU Law (OUP 1999) 727.

${ }^{39}$ C-320/91 Corbeau (n 34) para 16. Similar reasoning in contemporary cases see C-393/92 Almelo (n 8), para 114 C-157/94 Commission of the European Communities v Netherlands [1997] ECR I-5699; C-158/94 Commission of the European Communities v Italy [1997] ECR I-5789 and C-159/94 Commission of the European Communities v France (EDF/GDF)
} 
The role played by Article 14 TFEU has been and still is the subject of a legal debate. Admittedly, the provision contains only a compromise formulation which adds nothing to the content of Article 106(2) TFEU, and in particular cannot be used as a counterbalance to this provision. ${ }^{40}$ This line of reasoning was followed by Leigh Hancher, who expressed the opinion that Article 14 TFEU does not represent an amendment to Article 106 TFEU. ${ }^{41}$ The author further explained that 'It will however be open for a Member State to justify a particular restriction as being necessary to promote social and territorial cohesion (...). The promotion of such cohesion was however, implicitly recognized in Almelo and in Corbeau'. ${ }^{42}$ According to this interpretation Article 14 TFEU is no more than political window-dressing, changing nothing of substance.

Malcolm Ross, analysing the wording of the provision, stated that it appeared to be 'a triumph for ambiguous drafting and diplomacy insofar as it appears to support any interpretation along a spectrum running from defensive protection by Member States of their existing national public sector influence to the creation of a new communautaire concept of public service capable of horizontal application throughout Community law and policy'. ${ }^{43}$

On the other hand, the fact that Article 14 TFEU is placed in the Treaty among the fundamental principles of the EU means that it cannot be dismissed as an insignificant side-show. ${ }^{44}$ In this context Advocate General Jacobs expressed the opinion that 'Services of General Economic Interest have a special importance in the Community, as is now emphasised by Article 16 EC' [now Article 14 TFEU]. ${ }^{45}$ Despite the lack of a direct effect Article 14 TFEU represents a significant step in the concretising of non-economic concerns in both the psyche and legal hierarchy of the European Union. ${ }^{46}$ While leaving Article 106(2) TFEU and its acquis intact Article 14 TFEU provides a guidance mechanism for future interpretation of competition rules, as Alison Jones and Brenda Sufrin stated that this provision 'could be interpreted as simply giving Member States and entrusted undertaking more ammunition for justifying' privileges for SGEI operators' ${ }^{47}$ The authors further state that Article 14 TFEU is 'sending a message to the Court to continue on its present patch' regarding interpretation of Article 106(2) TFEU. $^{48}$

Article 14 TFEU emphasizes the place of Services of General Economic Interest among the shared values of the EU since they are essential for ensuring social and territorial cohesion and for the competitiveness of the European economy, and thus reflects a positive rather than derogatory

[1997] ECR I-5815. Article 14 TFEU was added as article 7D EC by the Treaty of Amsterdam.

${ }^{40}$ Hirsch, Montag and Säcker (n 11) 1267.

${ }^{41}$ Hancher (n 38) 730.

${ }^{42}$ ibid. Also inter alia cases C-393/92 Almelo (n 8) and C-320/91 Corbeau (n 34).

${ }^{43}$ Malcolm Ross, 'Article 16 EC and Services of General Interest: from Derogation to Obligation' (2000) 25 EL Rev 22.

${ }^{44}$ Jones and Sufrin (n 4) 673.

${ }^{45}$ C-475/99 Glöckner (n 24), Opinion of AG Jacobs, para 175.

${ }^{46}$ Leo Flynn, 'Competition Policy and Public Services in EC Law after Maastricht and Amsterdam Treaties' in David O'Keeffe and Patric Twomey (eds), Legal Issues of the Amsterdam Treaty (OUP 1999) 185.

${ }^{47}$ Jones, Sufrin (n 4) 673.

48 ibid 
approach towards the services in question. ${ }^{49}$ This is both a codification of preexisting case law and a further development elevating the importance of noneconomic values above those of a purely economic nature. ${ }^{50}$ Therefore, the provision in question could be seen as a rule of reason towards Article 106 (2) TFEU. As Advocate General Alber describes it, 'Article 16 EC [now Article 14 TFEU] and Article 36 of the Charter of Fundamental Rights of the European Union underline the importance of this exception as an expression of a fundamental value judgment of Community law'. ${ }^{51}$

It is probably too early to be sure, but since the Treaty of Lisbon came into force and especially with the inclusion of Article 36 of the Charter of Fundamental Rights, access to Services of General Economic Interest can be perceived in a rights-based constitutional context. The fundamental standing of SGEI is further augmented by the aforementioned Article 36 of the Charter of Fundamental Rights. The ECJ held that the Charter is to have the same legal effect as the Treaties. ${ }^{52}$ For now, however, the question remains open whether the discussed provision of the Charter contains enforceable rights or at least a defining principle. ${ }^{53}$

The Protocol on Services of General Interest serves as another example of the constitutionalisation process. However, one must take into account that protocols can only be used as a means to interpret the law. It may nevertheless serve as circumstantial evidence to prove a point. Especially when, as in this case, protocol reflects to a large extent recent developments in jurisprudence as well as in secondary law ${ }^{54}$. As Hans W Micklitz correctly pointed out, the services in question 'upgraded from a mere defence in Article 106(2) TFEU' to a fundamental value shared by the whole Union. ${ }^{55}$ This elevated the status of the SGEI concept from the competition policy level to the constitutional one. The focus of Services of General Economic Interest has thus shifted from economic considerations into promoting the needs of consumers, taking into account the geographical, cultural and social diversity of the Union ${ }^{56}$.

\footnotetext{
${ }^{49}$ Karayigit (n 30) 576.

${ }^{50}$ In this context the provision in question could be seen as a brake on liberalisation. See Erika Szyszczak 'Governance in the Context of Services of General Interest' (2002) 3 ERAForum: scripta iuris europaei 130.

${ }^{51}$ C-340/99 TNT Traco (n 34), Opinion of AG Alber, para 94.

52 See case C-275/06 Productores de Música de España (Promusicae) v Telefónica de España SAU [2008] ECR I-271, para 61 dated before Treaty of Lisbon entry into force and case C-555/07 Seda Kücükdeveci v Swedex GmbH \& Co. KG, para 22.

${ }^{53}$ See also Vasiliki Kosta 'Internal Market Legislation and the Private Law of the Member States. The Impact of Fundamental Rights' (2010) 6 ERCL 4.

${ }^{54}$ Ross (n 43) 88.

${ }^{55}$ Hans W Micklitz, 'Universal Services: Nucleus for a Social European Private Law' in Marise Cremona (ed), Market Integration and Public Services in the European Union (OUP 2011) 95 .

56 ibid.
} 


\section{DEROGATION OF THE TREATY RULES}

Article 106(2) TFEU is the instrument provided by the Treaty to strike a happy medium between market integration and economic efficiency objectives on the one hand, and equity objectives identified on national level on the other. ${ }^{57}$ Since the creation of the EC Treaty Article 106(2) TFEU has been the central provision regulating the operations of Services of General Economic Interest. The article in question allows deviations from the Treaty so far as are necessary in order to fulfil the particular general interest tasks assigned to undertakings.

Hence, the key question is if Article 106(2) is directly applicable. At first the ECJ denied its direct applicability. ${ }^{58}$ However, in its Ahmed Saeed and ERT ruling the Court implicitly recognized the direct applicability of the aforementioned provision, and finally in the INAIL case also did it explicitly. ${ }^{59}$ In this respect the ECJ dos not distinguish between sentences 1 and 2, and treats Article 106(2) TFEU as a directly applicable provision. ${ }^{60}$

The derogation encapsulated in Article 106(2) TFEU, as with any exception, must be interpreted strictly. ${ }^{61}$ It goes without saying that the mere invocation of the provision in question does not necessarily mean that the derogation will be applied. ${ }^{62}$ This is only possible if all the conditions set out in the provision are fulfilled. ${ }^{63}$ The first condition is that the service in question must have been 'entrusted' by the State. ${ }^{64}$ The second is that the restriction must be proportionate, and the third condition states that the interests of the Community (Union) must be respected. ${ }^{65}$ The application of the condition of proportionality has raised difficult questions especially when

57 C-202/88, France $v$ Commission of the European Communities (telecommunications terminals equipment) [1991] ECR I-1223.

${ }^{58}$ Cases 10/71 Hafen von Mertert (n 35), para 13; 172/82 Syndicat national des fabricants raffineurs d'huile de graissage and others $v$ Groupement d'intérêt économique "Inter-Huiles" and Others [1983] ECR 555

${ }^{59}$ Cases 66/86 Ahmed Saeed Flugreisen and Silver Line Reisebüro GmbH v Zentrale zur Bekämpfung unlauteren Wettbewerbs e.V [1989] ECR 803, para 56; C-260/89 Elliniki Radiophonia Tiléorassi AE (ERT) and Panellinia Omospondia Syllogon Prossopikou v Dimotiki Etairia Pliroforissis and Sotorios Kouvelas and Nicolaos Avdellas and Others [1991] ECR I-2925; C-218/00 Cisal di Battistello Venanzio \& C. v Instituto nazionale per l'assicurazione contro gli infortuni sul lavoro (INAIL) [2002] ECR I-691, para 16.

${ }^{60} \mathrm{C}-19 / 93$ Rendo NV, Centraal Overijsselse Nutsbedrijven NV and Regionaal Energiebedrijf Salland NV v Commission of the European Communities [1995] ECR I-3319. See also C19/93 Rendo (n 60), Opinion of AG Tesauro, para 38.

${ }^{61}$ Cases C-340/99 TNT Traco (n 34), para 56 and Case C-242/95 GT-Link A/S v De Danske Statsbaner (DSB) [1997] ECR I-4449, para 113.

62 Buendia Sierra (n 8) 590.

63 ibid.

${ }^{64}$ Joined Cases T-204/97 and T-270/97 Empresa para Agroalimentação e Cereais SA v Commission of the European Communities [2000] ECR II-2267, paras 125-128; Case 127/73 Belgische Radio en Televisie v SV SABAM and NV Fonior [1974] ECR 51. See also Cases C-309/99, Wouters (n 24), Opinion of AG Léger, paras 157-166; C-280/00 Altmark Trans GmbH and Regierungspräsidium Magdeburg v Nahverkehrsgesellschaft Altmark GmbH, and Oberbundesanwalt beim Bundesverwaltungsgericht [2003] ECR I-7747, Opinion of AG Léger, para 87.

${ }^{65}$ However Günther Hirsch, Frank Montag and Franz Jürgen Säcker expressed an opinion that is not entirely certain whether the 'interest of Community' criterion is stand-alone or should be interpreted in conjunction with the principle of proportionality. See Hirsch, Montag and Säcker (n 11) 1301. 
deciding on the compatibility of special or exclusive rights for operators entrusted with the provision of SGEI. ${ }^{66}$

As mentioned above, Article 106(2) TFEU is an exception, thus it can only be applied to a case if it is invoked by the Member State undertaking entrusted with a SGEI mission. ${ }^{67}$ Neither the Commission nor the ECJ is bound to apply this provision ex officio. ${ }^{68}$ The rule of thumb is that the Member State would have to prove that tasks of general interest have been entrusted to the undertaking and that the measure concerned was necessary and proportional. ${ }^{69}$

It is often reported that ECJ has interpreted the conditions justifying deviation from Treaty rules under Article 106(2) TFEU in a very restrictive way. ${ }^{70}$ However, the requirements of the jurisprudence for such a justification have been loosened since the mid-90's. Initially this applied to only those restrictions which are 'indispensable' in order to achieve a goal of general interest which are adduced..$^{71}$ This line of reasoning was further supplemented by the ECJ in its ruling in the BRT Sabam case, in which the Court stated that when faced with a particular measure in question what must be asked is whether or not other less restrictive measure exists by which this end could be achieved. ${ }^{72}$ As a result of this rigid approach Article 106(2) TFEU has rarely been found to apply. ${ }^{73}$

This approach has been modified, as in the Corbeau case the ECJ elaborated the notion of 'conditions of economic equilibrium' and 'economically acceptable conditions' under which the entrusted undertaking should perform its public mission task. ${ }^{74}$ According to the new, more flexible approach an undertaking entrusted with the operation of Services of General Economic Interest could be a subject of derogation under Article 106(2)

${ }^{66}$ Buendia Sierra (n 8) 591. See also Jürgen Schwarze, European Administrative Law (Sweet \& Maxwell 1992) 686.

${ }^{67}$ Davide Grespan, 'Services of General Economic Interest' in Wolfgang Mederer, Nicola Pesaresi and Marc Van Hoof (eds), EU Competition Law. Volume IV. State Aid. Book Two (Claeys \& Casteels 2008), para 4.1131.

68 ibid.

${ }^{69}$ Case C-159/94 EDF/GDF (n 39); 155/73 Giuseppe Sacchi [1974] ECR 409, para 15.

${ }^{70}$ See Tony Prosser, The Limits of Competition Law: Markets and Public Services (OUP 2005) $134-141$.

71 NAVEVA-ANSEAU (n 33), para 66; British Telecommunications (Case IV/29.877) Commission Decision 82/861/EEC [1982] OJ L360/42 and Cases C-18/88 Régie des télégraphes et des téléphones v GB-Inno-BM SA [1991] ECR I-5941 and C-155/73 Sacchi (n 69).

${ }^{72}$ Case 127/73 BRT (n 64). See also Cases 41/83 Italy $v$ Commission of the European Communities [1985] ECR 873; C-41/90 Höfner (n 16), para 24; C-179/90 Merci Convenzionali Porto di Genova v Siderurigica Gabrielle [1991] ECR I-5009; C-260/89 ERT (n 59), para 38; C-67/96 Albany International BV $v$ Stichting Bedrijfspensioenfonds Textielindustrie [1999] ECR I-5751; Joined Cases C-115/97 to C-117/97 Brentjens' Handelsonderneming $B V \quad v$ Stichting Bedrijfspensioenfonds voor de Handel in Bouwmaterialen [1999] ECR I-6025; C-219/97 Maatschappij Drijvende Bokken BV v Stichting Pensioenfonds voor de Vervoer-en Havenbedrijven [1999] ECR I-6121 and C266/96 Corsica Ferries France SA v Gruppo Antichi Ormeggiatori del porto di Genova Coop. arl, Gruppo Ormeggiatori del Golfo di La Spezia Coop. arl and Ministero dei Trasporti e della Navigazione.

73 Wolf Sauter, 'Services of general economic interest and universal service in EU law' (2008) 33 EL Rev 167.

${ }^{74}$ Case C-320/91 Corbeau (n 34), para 17. 
TFEU when normal competition rules 'obstruct' the performance, in law or in fact, of the particular tasks assigned to $\mathrm{it}^{75}$. In a number of cases that followed the ECJ accepted that an SGEI provider could be granted with special or exclusive rights only if normal market forces would 'threaten' its operations being performed under economically acceptable conditions. ${ }^{76}$

However, in the Air Inter case the Court returned to a stringent interpretation of the proportionality test, stating that granting exclusive rights is illegal as there are less restrictive means available to achieve goals of general interest. ${ }^{77}$ This apparent inconsistency can be explained by taking into account the traditional or newly-created character of a given SGEI and the presence or lack of EU secondary legislation in that sector. ${ }^{78}$

Nevertheless, the new, more lenient approach could be attributed to Article 14 TFEU. In other words, the Court recognises the value of public services independently of their economic viability; as Malcolm Ross pointed out, 'it clearly indicated that the availability of the derogation was to be measured by a balancing exercise based upon competing priorities rather than inhibiting that choice by insisting upon narrow economic tests to be satisfied before the normal market rules can be disapplied'. ${ }^{79}$ In other words, the role of Article 106(2) is shifting from a mere shield against other Treaty rules to a full-fledged legal instrument for maintaining the social dimension in the economy. ${ }^{80}$

\section{SGEI AND STATE AID}

In recent years the rules regarding State aid have moved to the centre of the Europe-wide regulatory debate over defining and regulating Services of General Economic Interest. ${ }^{81}$ State resources used for financing noneconomic activities are beyond the scope of EU competition and State aid law. When a State finances activities of an economic nature, direct finance or other benefits may be State aid subject to Commission approval and oversight. $^{82}$ The Treaty does not define State aid, but case law requires a given measure to meet five conditions: it must be attributable to a State, ${ }^{83}$ it must

\footnotetext{
${ }^{75}$ See also Leigh Hancher, 'Casenote on Corbeau' (1994) 31 CMLR 105.

${ }^{76}$ Cases C-157/94 Commission of the European Communities v Netherlands [1997] ECR I5699; C-158/94 Commission of the European Communities v Italy [1997] ECR I-5789; C159/94 EDF/GDF (n 39). See also Roth and Rose (n 21), para 11.052.

${ }^{77}$ Case T-260/94 Air Inter SA v Commission of the European Communities [1997] ECR II997.

${ }^{78}$ Buendia Sierra (n 8) 600.

${ }^{79}$ Ross (n 43) 25.

${ }^{80}$ Wolf Sauter and Harm Schepel (eds), State and Market in European Union Law. The Public and Private Spheres of the Internal Market before the EU Courts (CUP 2009) 191.

${ }^{81}$ Erika Szyszczak, The Regulation of the State in Competitive Markets in the EU (Hart 2007) 222.

82 ibid

${ }^{83}$ Joined cases 67/85, 68/85 and 70/85 Kwekerij Gebroeders van der Kooy BV and Others $v$ Commission of the European Communities [1988] ECR 219, para 37; 290/83 Commission of the European Communities v France (Credit Agricole) [1985] ECR 439, para 15 and 57/86 Greece v Commission [1988] ECR 2855, para 13. See also cases C-482/99 France v Commission of the European Communities (Stardust Marine) [2002] ECR I-4397, paras 55 and 56; C-303/88 Italy v Commission of the European Communities (ENI-Lancerossi) [1991]
} 


\section{SERVICES}

involve the transfer of national resources, ${ }^{84}$ it should constitute an economic advantage that the undertaking would not have received in normal market conditions, ${ }^{85}$ it must be selective, i.e. favour only certain undertakings, ${ }^{86}$ and finally it must have real or potential effect on competition and trade between Member States. ${ }^{87}$

The question of whether payment for Services of General Economic Interest can amount to state aid has produced extensive debate in the Commission and ECJ. The issue arises due to the broad definition given to the concept of state aid by the Commission and ECJ, and focuses on the effect of a measure rather than by reference to its causes or aims. ${ }^{88}$ Competing views have become known as the 'compensation approach', under which such measures are not regarded as State aid provided that they do not exceed the appropriate remuneration for the costs of the service in question, and the 'State aid approach' under which such measures should constitute State aid. ${ }^{89}$

ECR I-1433, paras 11 and 12; C-305/89 Italy v Commission of the European Communities [1991] ECR I-1603, paras 13 and 14.

${ }^{84}$ Martino Ebner and Edoardo Gambaro, 'The Notion of State Aid' in Alberto Santa Maria (ed), Competition and State Aid. An Analysis of the EC Practice (Kluwer Law International 2008) 18. See inter alia Cases T-214/95 Het Vlaamse Gewest (Flemish Region) $v$ Commission of the European Communities [1998] ECR II-717; 323/82 SA Intermills v Commission of the European Communities [1984] ECR 3809; Joined Cases 296 and 318/82 Netherlands and Leeuwarder Papierwarenfabriek BV v Commission [1985] ECR 809; C142/87 Belgium v Commission of the European Communities (Tubemeuse) [1990] ECR I959; C-303/88 Italy v Commission of the European Communities [1991] ECR I-1433; C305/89 Italy $v$ Commission of the European Communities [1991] ECR I-1603; 63/87 Commission of the European Communities v Greece [1988] ECR 2875; 102/87 France v Commission of the European Communities (Fonds industriel de modernisation) [1988] ECR 04067; Joined Cases C-15/98 and C-105/99 Italy (C-15/98) and Sardegna Lines - Servizi Marittimi della Sardegna SpA (C-105/99) v Commission of the European Communities [2000] ECR I-8855.

${ }^{85}$ Cases C-256/97 Déménagements-Manutention Transport SA (DMT) [1999] ECR I-3913. Also Case C-256/97 DMT, Opinion of AG Jacobs, para 31. case C-39/94 Syndicat français de l'Express international (SFEI) and others $v$ La Poste and Others [1996] ECR I-3547; C39/94 SFEI Opinion of AG Jacobs, para 60; Cases 173-73, Italy v Commission [1974] ECR 709, para 26; C-387/92 Banco de Crédito Industrial SA, now Banco Exterior de España SA $v$ Ayuntamiento de Valencia [1994] ECR I-877, paras 12 and 13; C-280/00 Altmark T-157/01, Danske Busvognmoend v Commission of the European Communities [2004] ECR II-917, para 57.

${ }^{86}$ Ebner and Gambaro (n 84) 27-28. See inter alia Cases C-143/99 Adria-Wien Pipeline GmbH and Wietersdorfer \& Peggauer Zementwerke GmbH v Finanzlandesdirektion für Kärnten [2001] ECR I-8365; T-55/99 Confederación Española de Transporte de Mercancías (CETM) $v$ Commission of the European Communities [2000] ECR II-3207; C-200/97 Ecotrade Srl v Altiforni e Ferriere di Servola SpA (AFS) [1998] ECR I-7907, para 36; 290/87 Netherlands $v$ Commission of the European Communities (Fisheries quotas) [1989] ECR I3083, paras 22-23; 61/79 Amministrazione delle finanze dello Stato v. Denkavit italiana Srl [1980] ECR 1205, para 31; T-260/97 R Camar v Commission of the European Communities and Council [1997] ECR II-2357, para 62.

${ }^{87}$ These conditions are usually treated together. See inter alia Joined Cases T-298/97, T312/97, T-313/97, T-315/97, T-600/97 to T-607/97, T-1/98, T-3/98 to T-6/98 and T-23/98 Alzetta Mauro and Others v Commission of the European Communities [2000] ECR II-2319, para 81 and case T-288/97 Regione Friuli Venezia Giulia v Commission of the European Communities [2001] ECR II-1169, para 41.

${ }^{88}$ Szyszczak (n 81) 223.

${ }^{89}$ Kelyn Bacon (ed), European Community Law of State Aid (OUP 2009), para 2.63. 
In FFSA and SIC cases the Court stated that financial compensation for SGEI operators must be qualified as State aid even if it can be held to be a benefit from the exception laid down in Article 106(2) TFEU. ${ }^{90}$ According to the Court, the notion of State aid is purely objective and does not require consideration of the reasons why the financial aid is granted by the State. Thus the fact that aid is granted to compensate public service obligations is not relevant at the stage of evaluating the merits of the case. ${ }^{91}$ This approach entails a number of procedural obligations for the Member States; existing aid must be monitored by the Commission and new aid cannot be implemented until it has been reported and approved by the Commission. ${ }^{92}$

This approach did not survive for long. In the $A D B H U$ ruling the Court expressed the opinion that transfers representing payments for performance of public service obligations did not amount to an 'advantage' to the undertaking and therefore did not constitute State aid under Article 107(1) TFEU $^{93}$. Similar reasoning can be observed in the Ferring judgment concerning tax levied on wholesale sales of medical products. ${ }^{94}$ The tax in question was intended to restore competitive balance between different wholesale distribution channels and to compensate for public service obligations imposed on certain undertakings in this sector. ${ }^{95}$ The ECJ, following the opinion of Advocate General Tizzano, took the view that a difference in treatment between undertakings did not automatically imply the existence of an 'advantage' for the purposes of definition of State aid under Article 107(1) TFEU. ${ }^{96}$

The proposition to reconcile these two approaches, the so-called 'quid pro quo approach' was presented by Advocate General Jacobs in his opinion in the $G E M O$ case. ${ }^{97}$ Jacobs proposed distinguishing between two situations: first, when is possible to see a 'direct and manifest link' between the financing granted by the State and clearly-defined public service obligations imposed to the beneficiary. In this case, the measure in question would not constitute State aid. In the second situation, when there is no such link or the public service obligation is vaguely defined, there would be room for qualification of such a measure as State aid. ${ }^{98}$

The groundbreaking Altmark case offered the opportunity to reconcile the different approaches. The ECJ set out four conditions, all of which must be satisfied for a measure not to constitute State aid. The first requirement is that the undertaking must have a clearly-defined public service obligation to

\footnotetext{
${ }^{90}$ Cases T-106/95 FFSA (n 34), para 167 and T-46/97 Sociedade Independente de Comunição (SIC) SA v Commission of the European Communities [2000] ECR II-2125, para 84.

91 ibid.

92 Article 108 TFEU.

${ }^{93}$ Case 240/83 Procureur de la République v Association de défense des brûleurs d'huiles usagées (ADBHU) [1985] 531, para 27.

${ }^{94}$ Case C-53/00 Ferring SA v Agence centrale des organismes de sécurité sociale (ACOSS) [2001] ECR I-9067.

${ }_{95}$ Bacon (n 79), para 2.66.

${ }^{96}$ Case C-53/00 Ferring (n 94), Opinion of AG Tizzano, para 61.

${ }^{97}$ Case C-126/01 Ministére de l'Économie, des Finances et de l'Industrie v GEMO SA. [2003] ECR I-13769

${ }^{98}$ Case C-126/01 GEMO (n 97), Opinion of AG Jacobs.
} 
discharge. ${ }^{99}$ It cannot simply be assumed from the nature of a given service. ${ }^{100}$ Also, the public service tasks in question must be 'external' to the operator concerned, and thus do not include measures in the interest of the undertaking (such as improvement of employee relations). ${ }^{101}$ The ECJ also pointed out that the obligation must be imposed over and above the duties normally incumbent upon the undertaking as provided by relevant sector-specific regulations or collective agreements. ${ }^{102}$

Second, the parameters of the basis on which compensation is calculated must be established in advance in a objective and transparent manner, to avoid overcompensation which may confer economic advantage on the recipient operator. ${ }^{103}$ In other words, this condition is designed to preclude any abuse of the SGEI concept. ${ }^{104}$

Third, the compensation cannot exceed what is necessary to cover all costs incurred in the discharge of the SGEI in question, taking into account the relevant receipts and a reasonable profit for the operator. ${ }^{105}$

Finally, when the undertaking which is to discharge public service obligation is not chosen pursuant to a tendering procedure, the level of compensation needed must be determined on the basis of analysis of the costs which 'a typical, well run undertaking' would have incurred in discharging those obligations. ${ }^{106}$ According to the ECJ, competitive selection of the entrusted SGEI provider is stated to be desirable by eliminating the suspicion of State aid, although this is not a necessity. ${ }^{107}$

In subsequent case law, notably in the $B U P A$, case the Court adopted a more permissive approach to the Altmark criteria, especially to the second, third and fourth. In that case there was no direct relationship between state measures and costs incurred by the undertakings and no comparison had been made between the costs of potential recipients of State payments and those of a typical, effective operator. ${ }^{108}$ The Court admitted that the aid scheme in question could not strictly fulfil the Altmark criteria; it held that the analysed

\footnotetext{
${ }^{99}$ Case C-280/00 Altmark (n 64), para 89 and T-289/03 BUPA (n 32), para 181.

${ }^{100}$ For a similar approach see Joined Cases C-34/01 to C-38/01 Enrisorse (n 36), paras 3334.

${ }^{101}$ See Case C-251/97 France $v$ Commission of the European Communities [1999] ECR I6639, Opinion of AG Fennelly, para 20.

102 Case C-280/00 Altmark (n 64), para 40 and T-157/01 Danske Busvognmoend (n 89), paras $75-83$ and 98.

${ }^{103}$ Case C-280/00 Altmark (n 64), para 90.

${ }^{104}$ Case T-289/03 BUPA (n 29), para 214.

105 Case C-280/00 Altmark (n 64), para 92.

$106 \mathrm{ibid}$, para 93. This condition in practice is rather difficult to satisfy. See The reform of the Dutch health care insurance system (RES) (Cases N 541/2004 and N 542/2004) Commission Decision of 03 May 2005 [2005] OJ C324/28, section 3.4.1; Spain-Financing of workforce reduction measures of RTVE (Case NN 8/2007) Commission Decision of 07 March 2007 [2007] OJ C109. Sometimes it is not even possible to identify such a 'typical efficient comparator'. See AVR - Commission Decision 2006/237/EC [2006] OJ L84/37, para 37.

107 See Christopher Bovis, 'Financing Services of General Interest, Public Procurement and State Aids: The Delimitation between Market Forces and Protection in the European Common Market' [2005] JBL 1.

${ }^{108}$ The previous Commission decision was based entirely on Article 106(2)TFEU. See Irish Health Insurance RES (Case N 46/2003) Commission Decision of 13 May 2003 [2003] OJ C186/16.
} 
scheme was consistent with its 'spirit and purpose'. ${ }^{109}$ It remains to be seen to what extent this more lenient approach will be followed in future cases. ${ }^{110}$ Let us consider as an example the post-Altmark BBC Digital Curriculum decision, in which Commission held that the fourth criterion was not been met as there had been no public procurement procedure, and public authorities failed to provide any relevant data as to whether the costs could be considered those of a 'typical, well run undertaking'. ${ }^{111}$ Yet the Commission proceeded to apply Article 106(2) to the State aid measure. ${ }^{112}$ On the contrary, in its ESB Ireland decision the Commission qualified a State measure as aid when authorities failed to provide an assessment of the costs of a typical operator. ${ }^{113}$ Notwithstanding the above, it seems that even if the Altmark criteria are not met, in practice most of the assessment of State aid for SGEI continues to take place under Article 106(2) and not Article 107(1) TFEU. ${ }^{114}$

It must be noted that, following the situation of legal uncertainty generated mostly by the Ferring judgment the Commission has adopted the so-called Altmark Package to clarify how it intends to apply the conditions of Article 106(2) TFEU in the State aid field according to principles formulated by the ECJ in its Altmark ruling. ${ }^{115}$ This attempt at clarification may be seen in the light of the political sensitivity of Services of General Economic Interest and their importance for society as a whole, as stressed by Article 14 TFEU. ${ }^{116}$ Quoting Jean-Marc Thouverin, 'European case-law is marked by a few cornerstones which constitute the main foundations of EC law. There is

\footnotetext{
${ }^{109}$ Case T-289/03 BUPA (n 29), paras 233 - 238.

${ }^{110}$ Bacon (n 89) 2.74. See also Max Klasse 'Services of General Economic Interest' in Martin Heidenhain (ed) European State Aid Law Handbook (C. H. Beck, Hart, Nomos 2010) 519.

111 BBC Digital Curriculum (Case N 37/03) Commission Decision of 1 October 2003 01.10.2003 [2003] OJ C271/47.

112 ibid. See also inter alia CADA Ireland (N 475/2003) Commission Decision of 16 December 2003 [2004] OJ C34/7; Busverkehr Landkreis Wittenberg (Case N 604/2005) Commission Decision of 16 May 2006 [2006] C207/2.

${ }_{113}$ Public Service Obligation - ESB Ireland (Case N 143/2004) Commission Decision of 14 July 2004 [2005] OJ C242/4.

${ }^{114}$ Leigh Hancher and Pierre Larouche, 'The Coming of Age of EU Regulation of Network Industries and Services of General Economic Interest' in Paul Craig and Grainne de Búrca (eds), The Evolution of EU Law. Second Edition (OUP 2011) 761.

115 So called Altmark Package consist of following acts: Commission Decision of 28 November 2005

on the application of Article 86(2) of the EC Treaty to State aid in the form of public service compensation granted to certain undertakings entrusted with the operation of services of general economic interest [2005] OJ L312/67; Community framework for State aid in the form of public service compensation [2005] OJ C297/4; Commission Directive of 28 November 2005 amending Directive 80/723/EEC on the transparency of financial relations between Member States and public undertakings as well as on financial transparency within certain undertakings [2005] OJ L312/47. See also not being part of the original package Commission staff working document - Frequently asked questions in relation with Commission Decision of 28 November 2005 on the application of Article 86(2) of the EC Treaty to State aid in the form of public service compensation granted to certain undertakings entrusted with the operation of services of general economic interest, and of the Community Framework for State aid in the form of public service compensation - Accompanying document to the Communication on 'Services of general interest, including social services of general interest: a new European commitment' SEC/2007/1516 final .

${ }^{116}$ Grespan (n 67), para 4.1210.
} 
no doubt that decisions like for example Van Gend en $\operatorname{Loos}^{117}$, Costa ${ }^{118}$, Simmenthal ${ }^{119}$, AETR $^{120}$, Rutili $^{121}$ are clearly amongst them, but it seems that the same could be said for the Altmark decision'. ${ }^{122}$ True enough, but the reality of application of the Altmark criteria seems ambiguous.

\section{CONCLUSIONS}

This paper attempts to put the development of EU regulation of Services of General Economic Interest within the discussion of competing social and market paradigms. Ever since the Treaties came into existence the possibility of conflict has existed between the powers of Member States to organize markets for SGEI and EU competition rules. Is a more permissive approach for deviation from Treaty rules for undertakings entrusted with providing Services of General Economic Interest together with the apparent change of focus of the European Union's goals enabling a fleshing-out of the skeleton of a new European concept of public services?

Much progress has been made but the final picture is not yet clear. As Malcolm Ross observes, 'The political and legal mandate contained in Article 16 EC [now 14 TFEU] provides a benchmark against which responsibilities of principal actors involved with public services can be ascribed and developed. But there remains a governance challenge since the content of those responsibilities, coalescing around the core solidarity principles which are served and protected by public services, cannot be imposed from "on high" but must be grown from processes, evaluations and co-operative advocates in calls for a horizontal directive'. ${ }^{123}$

Taking into account imprecise terminology, the rather blurred objectives of the European Union regarding Services of General Economic Interest as well as the not entirely clear distribution of competences between the EU and Member States and also the differences in legal traditions regarding the services in question between the States in the EU, it seems at the moment a European model of public services does not exist or is at least is in statu nascendi. However, rulings like Corbeau or Altmark as well as secondary legislation harmonising certain sectors alongside the ongoing process of the elevation of the right of access to services in question to the constitutional level has covered significant ground in terms of common rules

\footnotetext{
117 Case 26/62 NV Algemene Transport- en Expeditie Onderneming van Gend \& Loos v Nederlandse Administratie der Belastingen [1963] ECR 3 (direct effect).

118 Case 6/64 Flaminio Costa v E.N.E.L. [1964] ECR 1141 (supremacy).

119 Case 106/77 Amministrazione delle Finanze dello Stato v Simmenthal SpA [1978] ECR 629 (supremacy).

${ }^{120}$ Case 22/70 Commission of the European Communities v Council (ERTA/AETR) [1971] ECR 263 (external EC competence).

${ }^{121}$ Case 36/75 Roland Rutili v Ministre de l'intérieur [1975] ECR 1219 (public order and free movement of persons).

122 Jean-Marc Thouvenin, 'The Altmark Case and Its Consequences' in Krajewski, Neergaard and van de Gronden (n 1) 103.

${ }^{123}$ Malcolm Ross, 'Promoting Solidarity: From Public Services to a European Model of Competition?' (2007) 44 CMLR1057.
} 
for SGEI regulation. ${ }^{124}$ Therefore it is probably safe to say that a European concept of public services lies in the not-too-distant future.

${ }^{124}$ See also Cremona (n 55). 